\title{
New evidence on the spatial organisation of the Valencina de la Concepción Copper Age settlement: geophysical survey between La Pastora and Montelirio
}

\author{
Nuevas evidencias sobre la organización espacial del asentamiento de la Edad del Cobre \\ de Valencina de la Concepción: prospección geofísica entre La Pastora y Montelirio
}

\author{
David Wheatley (*) \\ Kristian Strutt (*) \\ Leonardo García Sanjuán $(* *)$ \\ Coronada Mora Molina (**) \\ José Peinado Cucarella (***)
}

\begin{abstract}
The major Copper Age settlement of Valencina de la Concepción has been the subject of research interest over more than a century. The history of previous investigations at the site has resulted in a heterogeneous archaeological record that is particularly difficult and that displays significant gaps and problems. In this paper, we present the results of a geophysical survey carried out in December 2004 between the La Pastora and Montelirio sectors of this site in response to a proposed road development that was never put into practice, and which revealed several previously unknown features. These data are assessed in the light of the results obtained from the excavation carried out between 2007 and 2008 at the immediately adjacent sector of PP4-Montelirio, currently under study by us, where several dozen prehistoric features (both, non-megalithic and megalithic, funerary and non-funerary), were found. Altogether, this new evidence makes a significant contribution to the spatial interpretation of the Valencina de la Concepción site, particularly as they convey the first-ever cartography of a large area of this settlement. From this evidence, a discussion is made concerning the density and diversity of the features identified both between La Pastora and Montelirio as well
\end{abstract}

(*) Archaeology, Faculty the Humanities, University of Southampton. Highfield. Southampton. Reino Unido.

E-mail: dww@soton.ac.uk; K.D.Strutt@soton.ac.uk

(**) Dpto. de Prehistoria y Arqueología, Universidad de Sevilla. C/ María de Padilla s/n. 41004 Sevilla. España.

E-mail: 1garcia@us.es; coronada mora@hotmail.com

(***) Arqueólogo Profesional. C/ Mare Vella 216. 46003

Valencia. E-mail: ppq@hotmail.com

Received: 30-IV-2011; accepted: 16-VI-2011. as at the PP4-Montelirio sector, their potential patterns and sequence. This raises questions regarding the traditional separation of the site into 'settlement' and 'necropolis' areas and contributes more generally to a better understanding of the spatial organisation of this large prehistoric settlement.

\section{RESUMEN}

El gran asentamiento de la Edad del Cobre de Valencina de la Concepción ha sido objeto de numerosas investigaciones a lo largo de más de un siglo. Estas investigaciones han dado lugar a un registro arqueológico heterogéneo particularmente dificil de interpretar, y que presenta importantes vacios y problemas. En este artículo se exponen los resultados de una prospección geofisica realizada en diciembre de 2004 entre los sectores de La Pastora y Montelirio en conexión con el proyecto de construcción de una carretera que finalmente nunca se llevó a cabo. Estas prospecciones revelaron numerosas estructuras previamente desconocidas. Los datos de esta prospección geofísica son valorados a la luz de los resultados obtenidos en la excavación llevada a cabo entre 2007 y 2008 en el sector inmediatamente adyacente de PP4-Montelirio, actualmente en proceso de estudio por nuestra parte, donde se identificaron varias decenas de estructuras prehistóricas (negativas no-megaliticas y megalíticas, funerarias y no-funerarias). Estos resultados arrojan nueva luz de cara a la interpretación espacial del asentamiento de Valencina de la Concepción posibilitando, por primera vez, cartografiar un sector amplio del mismo. A partir de estas nuevas evidencias se debaten cuestiones relativas a la densidad y diversidad de las estructuras presentes entre La Pastora y Montelirio asi 
como en el propio sector PP4-Montelirio, sus posibles patrones espaciales y funcionales así como su diacronía. Esto plantea preguntas con respecto a la clasificación tradicional del sitio en zonas diferenciadas de "hábitat" $y$ "necrópolis" y contribuye en general a una mejor comprensión de la organización espacial de este gran asentamiento prehistórico.

Key words: Copper Age; Iberia; Geophysics, Magnetometry; Megaliths; Negative Features; Archaelogy of management.

Palabras clave: Edad del Cobre; Iberia; Geofísica; Magnetometría; Megalitos; Estructuras Negativas; Arqueología de gestión.

\section{INTRODUCTION}

Nurtured by the steady flow of new empirical findings and by competing theoretical approaches, the Iberian Copper Age (or 'Chalcolithic') period, spanning between $c .3200$ and 2100 cal $\mathrm{BC}$, has generated intense academic debate since the 1980s. Following early papers (for example Arribas Palau \& Molina González 1984; Gilman 1987; Chapman 1990), a growing literature in English has recently begun to make this more accessible to an international audience, particularly with respect to issues surrounding settlement patterns, economic intensification, metallurgy, burial practices and social inequality. Prominent in this literature are sites in Spain such as Los Millares, in Almería (Micó Pérez 1995; Esquivel Guerrero and Navas Guerrero 2005, 2007; Navas Guerrero et al. 2008), La Pijotilla (Hurtado Pérez 2000, 2010) and San Blas, in Badajoz (Hurtado Pérez 2004; Kohring et al. 2007); Cabezo Juré, in Huelva (Nocete Calvo, 2006), as well as Portuguese sites such as Leceia (Cardoso 2000; Muller \& Cardoso 2008) and Vila Nova de São Pedro (Müller \& Monge Soares 2008) in Estremadura and Alcalar in the Algarve (Morán Hernández 2010). The evolution of some the issues under discussion is well reflected in papers by Gilman 1987, 2002; DíazAndreu 1995; Chapman 1995, 2008; Díaz-delRío 2004, 2011.

The Copper Age settlement of Valencina de la Concepción, Castilleja de Guzmán (henceforth 'Valencina') is located in the province of Sevilla and has recently begun to be discussed in papers aimed at international audiences (Nocete Calvo et al. 2008; García Sanjuán 2009; Costa Caramé et al. 2010). Notable for its very large area - the prehistoric evidence may cover up to 400 ha and its substantial megalithic monuments, Valencina is situated on the higher ground of the Aljarafe platform to the west of the Guadalquivir River valley, about six kilometres from the city of Seville (Fig. 1).

Archaeological research at Valencina dates back to the late 19th century and has continued sporadically to the modern era of developer-funded archaeology. Early work focused on the outstanding megalithic monuments of La Pastora, Matarrubilla, and Ontiveros (Tubino 1876; Obermaier 1919; Carriazo \& Arroquia 1962; Collantes de Terán 1969). This revealed the very significant scale of the monumentality associated with Valencina, emphasising the importance of the settlement and establishing the largely uncontested view that it represents a large, single-phase settlement with an associated necropolis that demonstrates a single tradition of burial practices.

From the mid-1970's onwards, several features found largely in the northern part of the site (beneath the modern settlement of Valencina) have been interpreted as domestic or productionrelated (Fernández Gómez \& Oliva Alonso 1986; Murillo Díaz et al. 1987; Blanco Ruiz 1991; Ruiz Moreno 1991; Martín Espinosa \& Ruiz Moreno 1992; Santana Falcón 1993; Arteaga Matute \& Cruz-Auñón Briones 1999; Cruz-Auñón Briones \& Arteaga Matute 1999a, 1999b; Ruiz Moreno 1999; López Aldana et al. 2001; Vera Fernández et al. 2002; Nocete Calvo et al. 2008). Structures identified include cut features referred to as 'silos' that are conventionally interpreted as grain storage pits, 'hut floors' (fondos de cabaña), 'dumps', 'ditches' and 'trenches'. Metal production is now well documented by the presence of furnaces, crucibles and slag in certain areas (Nocete Calvo et al. 2008). The production of a Carta Arqueológica (inventory) of the excavations carried out at the site (Ruiz Moreno 1995, Vargas Jiménez 2004a, 2004b) represented a significant advance in the systematization of information and assessment of its organization. In addition to this, a number of papers have attempted to place the evidence within a broader interpretative and historiographic framework of the site has also received some attention (Ruiz Mata 1983; Martín de la Cruz \& Miranda Ariz, 1988; Murillo Díaz 2001; Gómez de Terreros Guardiola 2005, 2008). 


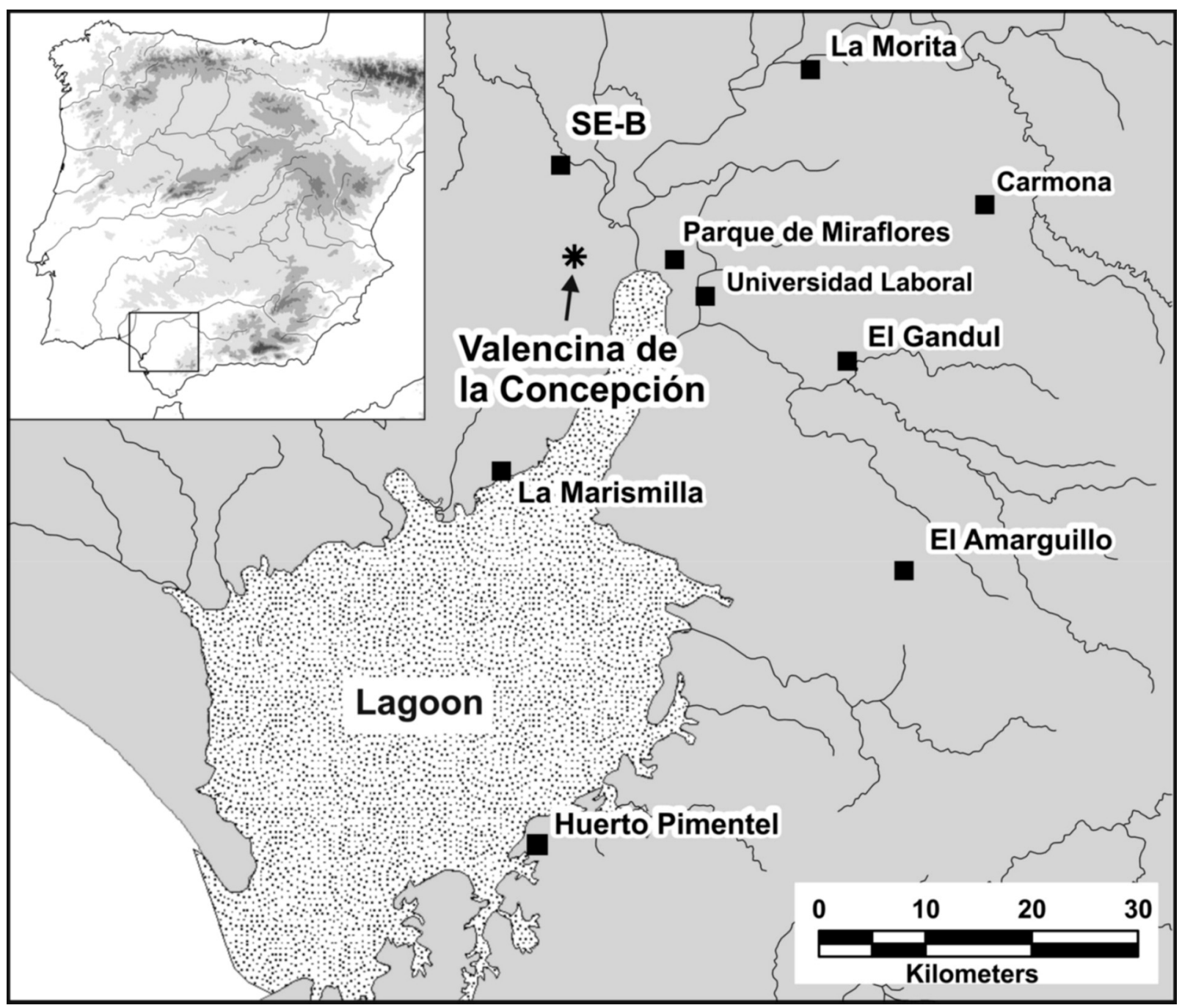

Fig. 1. Valencina de la Concepción (Sevilla). Location in relation to other excavated sites of the 3rd and 2nd millennia $\mathrm{cal} \mathrm{BC}$ in the lower Guadalquivir valley. The main map also shows the estimated outline of the coastline during Late Prehistory.

The density of these investigations (Fig. 2) arguably makes Valencina the most intensively excavated Copper Age settlement in Iberia.

Since the 1970 s a number of previously unrecorded, generally smaller, megalithic constructions have been discovered, mainly as the result of rescue excavations (Fernández Gómez \& Ruiz Mata 1978(1); Murillo Díaz et al. 1990; Murillo

(1) Cabrero García, R. 1985: "El sepulcro megalítico de Caño Ronco (Camas, Sevilla) y su vinculación con el yacimiento calcolítico de Valencina de la Concepción". Prehistoria 1: 1-16. Unpublished manuscript.
Díaz 1991; Santana Falcón 1991; Ruiz Moreno \& Martín Espinosa 1993; Martín Espinosa \& Ruiz Moreno 1995; Ruiz Moreno \& Martín Espinosa 1995; Arteaga Matute \& Cruz-Auñón Briones 1999; Arteaga Matute \& Cruz-Auñón Briones 2001). In 1998 a significant major megalithic structure, Montelirio, was also identified; excavations carried out between 2007 and 2009 have demonstrated that this is another major megalithic structure similar in scale to La Pastora and Matarrubilla (their locations are shown in Fig. 3). The results of the Montelirio excavations remain unpublished at the time of writing. 


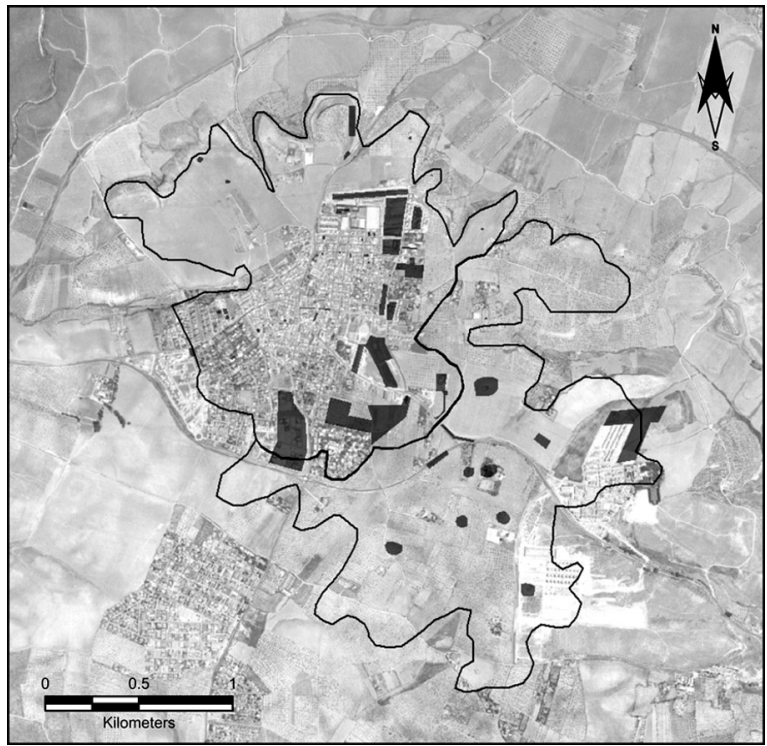

Fig. 2. Valencina de la Concepción (Sevilla). Orthophotograph showing the perimeter of the site and the locations (shown as darker tones) of known archaeological investigations (after Vargas Jiménez 2004: 49).

Because of its extent, monumentality, density and diversity of domestic and funerary features, Valencina is a uniquely valuable resource for the investigation of issues that feature high on the agenda of Iberian Copper Age research such as the relationship between spatial extension and demographics, the scale and social role of metallurgy, economic specialisation, metallurgical production, spatial organisation, diversity of funerary practices and social ranking. However, the empirical evidence currently available for Valencina has several problems. The diversity and lack of coordination of the archaeological interventions carried out has led to an archaeological record that is extremely heterogeneous, varying significantly in precision, accuracy and reliability and which is therefore very difficult to interpret. The vast majority of recent investigations have been 'rescue' excavations and many different teams have worked in small areas of the site, often without coordination. The reports and studies produced have often been superficial and have lacked detailed post-excavation analysis.

This paper addresses one of the main problems currently hampering a more accurate interpretation of this prehistoric settlement, namely the lack of overall data relating to its spatial or- ganization. This problem is a result of the whole northern sector of the site lying beneath the modern town of Valencina. Most of the excavations carried out there (which result from urban development) have consequently covered rather small land plots, making it very difficult to assess the layout of ditches and other negative features at a larger scale (especially in the light of this site's particularly large scale). This problem is further compounded by the lack of a unified digital cartography for the hundreds of archaeological features that have been identified and excavated over the years. Some of the most relevant problems regarding the Valencina Copper Age community (productive specialization, social zoning, diachrony, etc.) will remain practically intractable unless large areas of the site are mapped and evidence of its spatial distribution becomes available (Costa Caramé et al. 2010).

Thus, this paper is aimed as a preliminary description and discussion, for the first time, of the spatial distribution of a relatively large sector of the settlement. In December 2004, a geophysical survey was carried out by Kristian Strutt of the University of Southampton on behalf of the Inserco engineering company and the Junta de Andalucia (2) of a transect located at the southern part of Valencina, between the La Pastora and Montelirio sectors (Fig. 3). This survey is particularly important for a number of reasons. Firstly, this is the first-ever geophysical exploration of Valencina. Only very recently, the full potential of geophysics for the study of large-scale, spatially-complex southern Iberian Copper Age settlements has begun to be appreciated (Morán Acuña 2010; Valera et al. 2011). Secondly, the surveyed transect is within the largest non-built area of the site, basically formed by the triangle between the La Pastora, Montelirio and Matarrubilla megalithic monuments. This is therefore a very important scientific 'reserve' of Valencina, an area still unspoiled by urban growth and available for future research. Thirdly, the area covered by this transect (approximately 5.5 hectares) is quite significant, which makes it highly representative of the kind of evidence characteristic of this whole sector of the site. Finally, a fourth reason that adds to the relevance of this fieldwork

(2) Strutt, K. 2005: Valencina de la Concepción, Seville Geophysical Survey Report January 2005. Southampton, University of Southampton. Unpublished Report. 


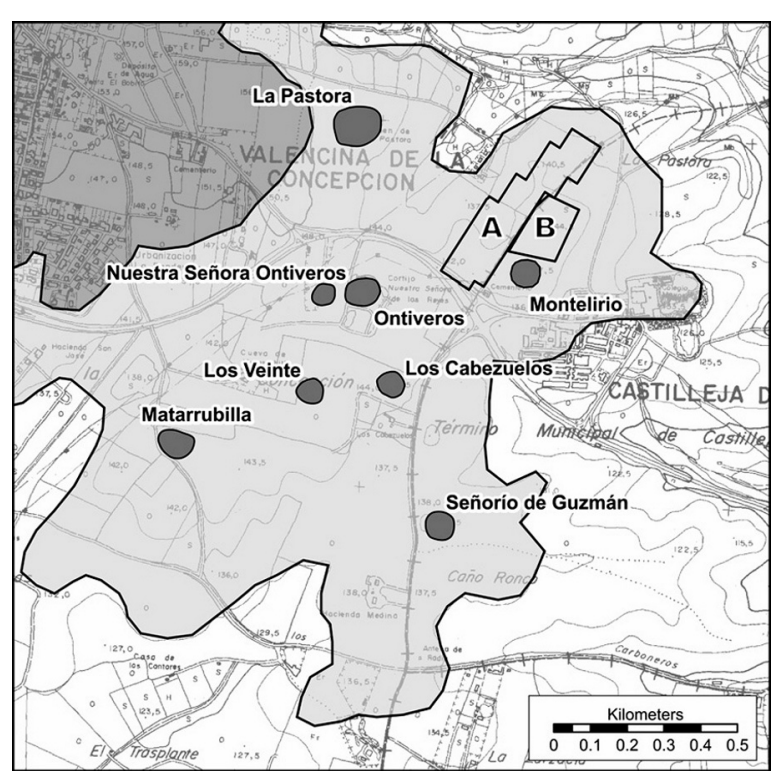

Fig. 3. The southern sector of Valencina de la Concepción (Sevilla) (shaded in lighter grey) showing the locations of the 2004 magnetometer survey (A), the extent of 2007-2008 excavations at PP4-Montelirio (B) and the locations of some of the major megalithic monuments.

is that, crucially, the surveyed transect is neighboring with the PP4-Montelirio sector of Valencina, which was excavated between 2007 and 2008 by one of the authors (JPC) (3). Thanks to this circumstance, not only it has been possible to see the results of the geomagnetic survey in the light of the evidence obtained in that excavation, but it has been also possible to join together the interpretative plan resulting from the magnetometry with that of the PP4-Montelirio excavation to create, for the first time ever, a large-scale cartography for part of Valencina.

\section{DESCRIPTION OF THE SURVEY}

Magnetometry (4) was chosen as the most appropriate technique for its efficiency (Gaffney et

(3) The Plan Parcial 4-Montelirio record, including over hundred prehistoric features (non-megalithic and megalithic, funerary and non-funerary), is currently under study by the authors of this paper.

(4) The survey used two Geoscan Research FM36 fluxgate gradiometers to survey $30 \mathrm{~m} \times 30 \mathrm{~m}$ grids located on a north-south axis. Readings were taken at $0.5 \mathrm{~m}$ intervals along $1 \mathrm{~m}$ traverses, and then processed using Geoplot 3.0 software. Data has been al. 1991: 6) and its ability to locate features such as burials, pits, kilns, hearths, ovens and ditches (Scollar et al. 1990: 362; Geoscan Research 1996; Marshall 1999). No geophysical survey had previously been conducted in the area, and previous excavations and investigations in the southern sector of the site had been mainly explorations of extant megalithic tombs. Therefore there was little work to assess the range of prehistoric structures that may have existed in between these.

The survey results indicated a significant number of features, which have been separated into north and south to enable sufficient detail to be reproduced, and shown in figures 4.1 and 5.1 while the identified magnetic anomalies are highlighted and numbered in the corresponding figures 4.2 and 5.2. In the southern part of the survey area (Figs. 4.2 and 5.2) two main concentrations of features are visible. At the southern limit of the survey, two dipolar linear anomalies ( $\mathrm{m} 1$ and $\mathrm{m} 2$ ) appear to be modern pipelines. To the north of these is a large group of positive discrete anomalies (m3) measuring some $45 \mathrm{~m}$ from north-south, and 30m east-west. The individual magnetic anomalies range from $2 \mathrm{~m}$ to $4 \mathrm{~m}$ in diameter, and all indicate features cut into the subsoil. Some of the anomalies in this area (such as $\mathrm{m} 4$ and $\mathrm{m} 5$ ) are curvilinear, measuring in some instances $5-10 \mathrm{~m}$ in length. The concentration of features follows the edges of the low hill on the south side of the survey area (m6), running to the edge of the survey (m7). The anomalies in this area are elongated in shape and orientation, suggesting that they may have been badly eroded by modern plough activity over the hillside. A small number of discrete features are present on the lower slopes of the hill (m8), bounded on their north eastern side by a broad curvilinear band of readings $(\mathrm{m} 9)$ that runs for a distance of over $16 \mathrm{~m}$ towards the farm building and dry valley to the north. This may mark the line of a road that cut through the shallow valley between Montelirio and the low hillside to the west. A number of further positive features (m10) are visible in this area to the south of (m9). There is a second concentration of positive magnetic anomalies

\footnotetext{
'despiked' to remove large peaks, a 'mean traverse' function has been applied to average out 'drift' in the earth's magnetic field during the survey and $0.5 \mathrm{~m}$ values have been interpolated to equalize the spatial resolution in the $\mathrm{x}$ and $\mathrm{y}$ axes.
} 
(m11) on the slope to the north of Montelirio. The large dipolar signal (m12) located on the north east edge of this concentration is caused by a modern electricity pylon while the positive anomalies (m13) and (m14) are in all probability created by the remains of ferrous material associated with a modern fence that has since been removed.
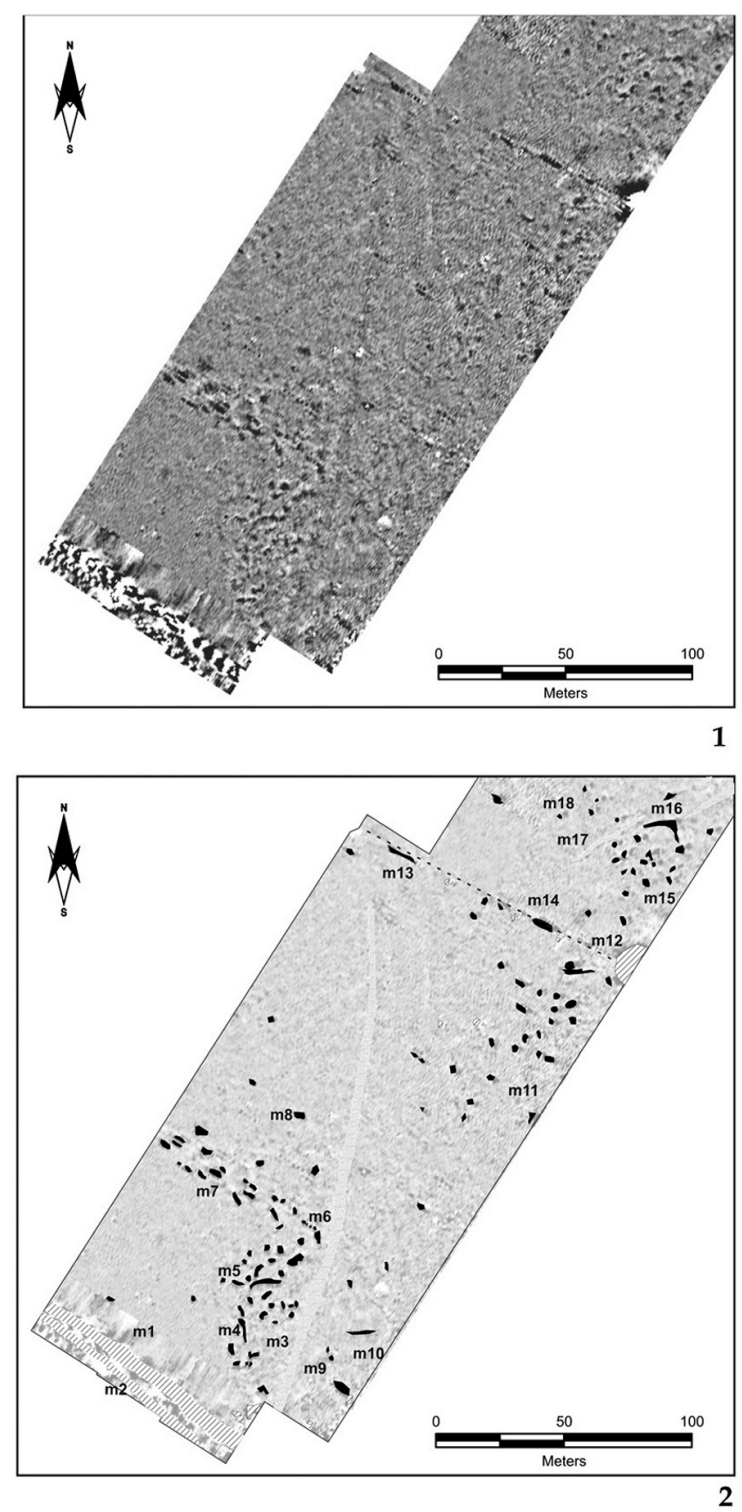

Fig. 4. Valencina de la Concepción (Sevilla), the southern part of the survey area 1) Greyscale image of the magnetometer. 2) Interpretation plot derived from the magnetometry.
Several features are visible to the north of the old fence (Fig. 5) including around 10-15 discrete features $(\mathrm{m} 15)$ and a slight rectilinear positive feature (m16) marking a ditch or enclosure. A broad band of positive readings (m17) is orientated south-west to north-east, and extends for over $80 \mathrm{~m}$ with a break in the centre. This appears to mark the line of a track or road running di-
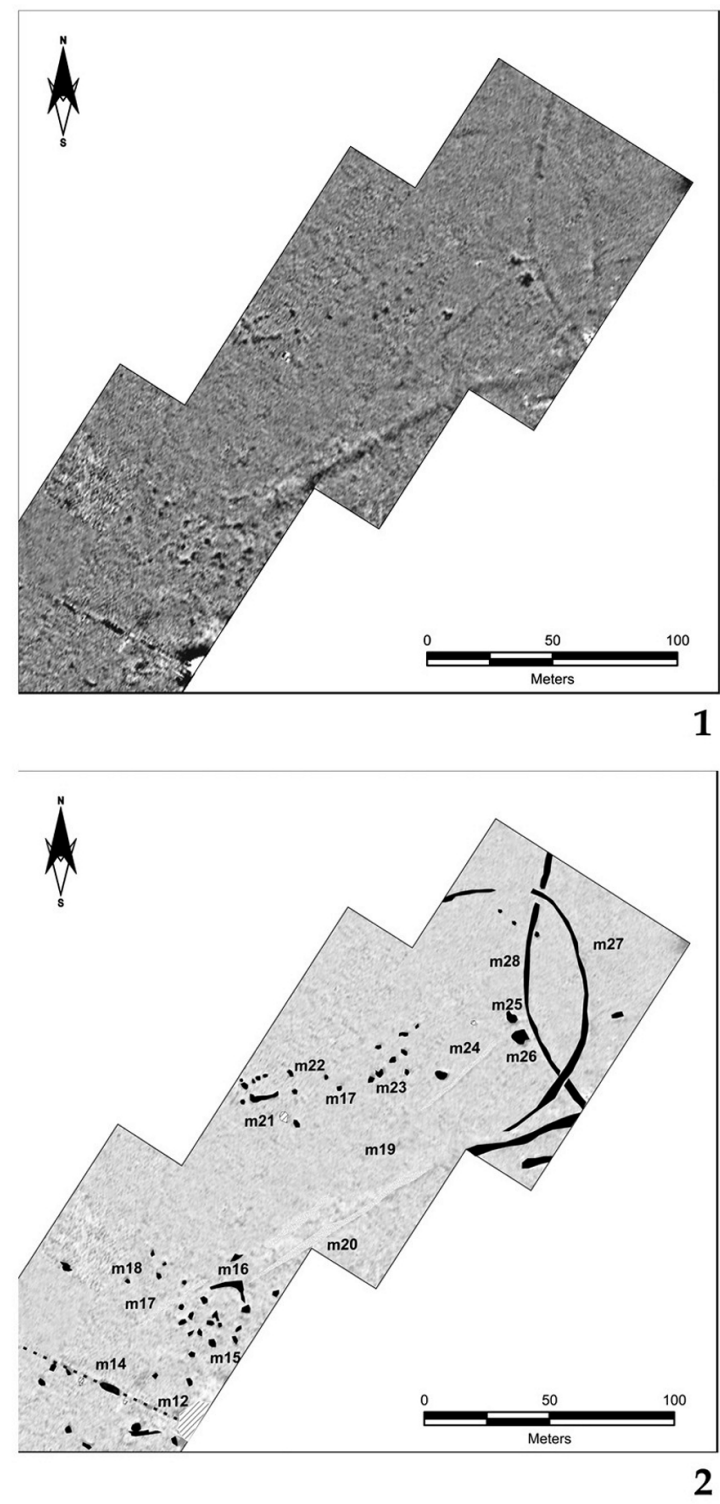

Fig. 5. Valencina de la Concepción (Sevilla), the northern part of the survey area 1) Greyscale image of the magnetometer. 2) Interpretation plot derived from the magnetometry. 
rectly between $(\mathrm{m} 25)$ and $(\mathrm{m} 26)$ some $120 \mathrm{~m}$ further north (see below). Once again, a number of features are visible down the slope from the main concentration $(\mathrm{m} 18)$. Two potential roads or tracks (m19) and (m20) run north and north-west, while on the summit of the small hill, a series of discrete and linear anomalies $(\mathrm{m} 21)$ form a rectilinear feature on the hilltop, a form that is strongly suggestive of a construction of some kind. Two discrete anomalies mark the north east extent of the feature $(\mathrm{m} 22)$, and a line of similar pit features (m23) runs to the north east. An interesting formation of archaeological features occurs where the line of the road (m24) continues down the slope: it passes between two positive features (m25) and (m26), the former c. $9 \mathrm{~m}$ in diameter, and the latter c. $6 \mathrm{~m}$ in diameter which could represent large burial pits or silos. Two enclosure ditches (m27) and (m28) are visible on the northeastern confines of the survey results. The easternmost (m27) runs for a distance of over $100 \mathrm{~m}$ in a broad curve, and is crossed by the second (m28), which curves for over $130 \mathrm{~m}$, meeting the line of the road feature $(\mathrm{m} 20)$. The exact nature of these features is difficult to determine, although one apparently predates the other.

\section{INTERPRETATION}

The results of the geophysical survey indicate significant archaeological deposits present in the area around Montelirio. In total, there are at least 160 identified anomalies, some of which are of very significant size. Although not all of these anomalies will be of prehistoric date (there is strong evidence of Roman activity in the area, as shown in PP4-Montelirio), this implies a very significant density of structures. The significance of these anomalies may be better appreciated when the survey results are examined in the light of the evidence unearthed by the rescue excavation carried out at Plan Parcial 4-Montelirio (5) which is directly adjacent to the geophysical survey (Fig. 6). A full programme of post-excavation and radiocarbon dating of PP4-Montelirio is cur-

(5) Peinado Cucarella, J. 2009: Memoria arqueológica del plan parcial sector PP4 "Dolmen Montelirio" en el Término Municipal de Castilleja de Guzmán (Sevilla). Delegación de Cultura, Junta de Andalucía. Sevilla. rently under way, but the general characteristics and spatial distribution of the features identified in this excavation bear significantly on the interpretation of the earlier geophysical survey.

The area of PP4-Montelirio that was fully investigated, covering approximately $130 \mathrm{~m} \times 120 \mathrm{~m}$ (1.5 hectares), revealed an estimated 211 structures and deposits (this figure is still in the process of being assessed by the post-excavation study). Most of these appeared after removal of between 0.5 and $1 \mathrm{~m}$ of topsoil. Of these, 134 are of prehistoric date, mostly corresponding to the Copper Age, 24 are of Roman date, 44 are post-Roman date and 5 are chronologically undetermined. Among those of prehistoric date, most are, according to a preliminary assessment of their materials, of Copper Age date, although some others, pending the results of $\mathrm{C} 14$ analyses, may prove to be of Bronze Age date. Out of the 140 prehistoric features, 61 have been provisionally classified as of funerary character (they contain human remains) and 73 as non-funerary (they do not contain human remains) (Fig. 7: 1) gives a general perspective of the site during the excavation.

The types of funerary structures found at PP4Montelirio are known widely within southern Iberia during the $3 \mathrm{rd}$ millennium cal BC. A minority of them may be described as 'megalithic'; they consist of rock cut circular chambers (up to $2 \mathrm{~m}$ in diameter) defined and lined by slate uprights (Fig. 7: 2). Examples present at PP4Montelirio include two examples of 'double' tombs comprising two chambers joined by a short passage leaving the first chamber at an angle. These appear in the centre of areas of approximately 40-50m diameter which are largely devoid of other Chalcolithic structures, leading to the possibility that each was covered with a mound or protected in some way from 'satellite' burials and activity. Other 12 rock-cut funerary structures have some stone elements, but they cannot be described as "megalithic" because of the scarcity of stones (let alone large stones) and because those stones do not play a fundamental architectural role. Finally, there is a further 43 rock cut structures without any stone architecture, mostly consisting in circular, pseudo-circular or irregular shallow pits (Fig. 7: 3). An in-the-field preliminary estimate sets at $c .150$ the number of buried individuals, but this figure may well be significantly increased once the anthropological study is completed. 


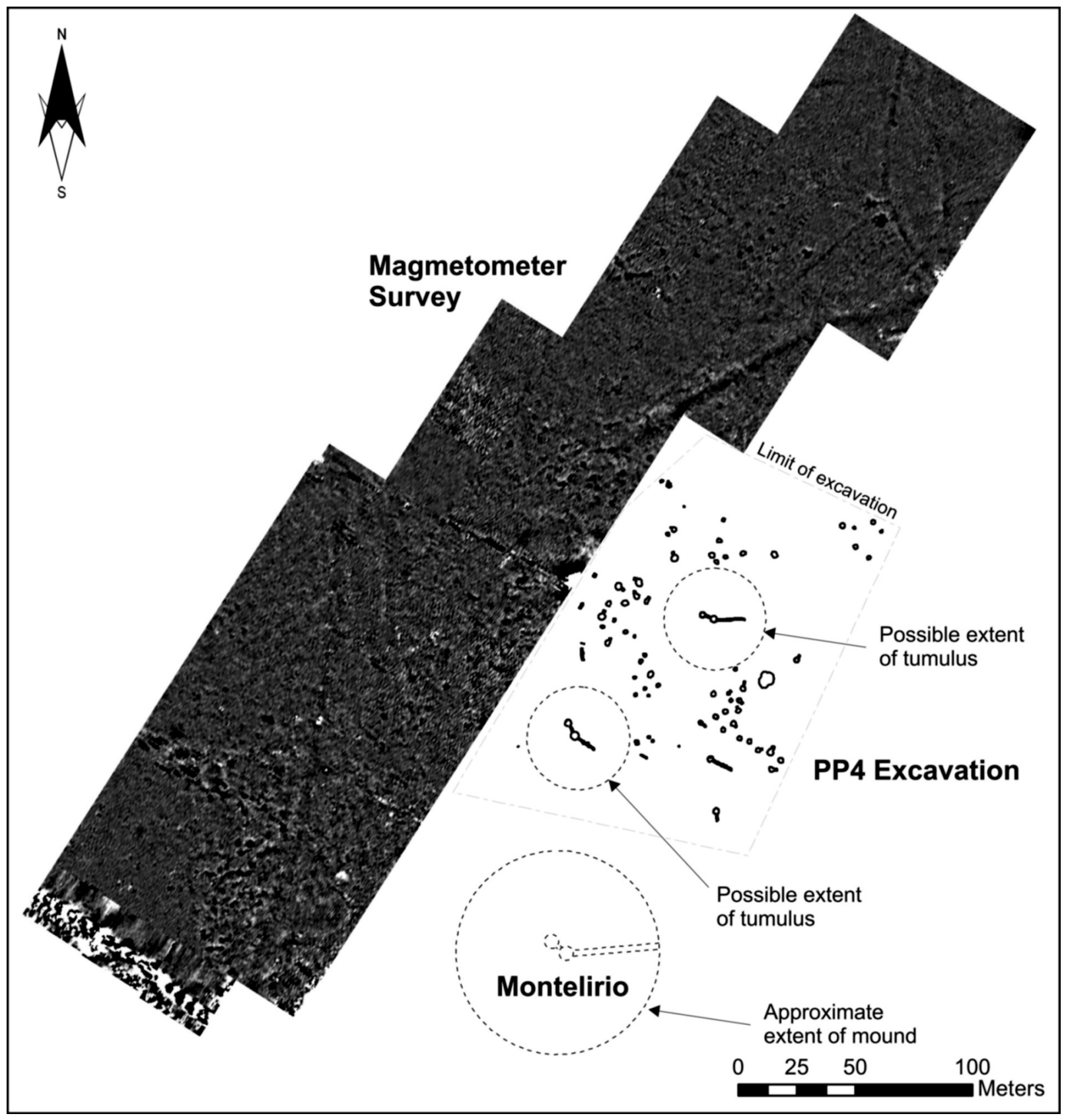

Fig. 6. Valencina de la Concepción (Sevilla), summary plans of the geomagnetic survey and the main features encountered in the PP4 excavations (not all features are shown, and not all the features shown for PP4 were excavated), also showing the approximate position and orientation of the Montelirio passage grave. PP4 = Plan Parcial sector 4, Término Municipal Castilleja de Guzmán, Sevilla.

The 73 non-funerary structures found at PP4Montelirio include a number of what were interpreted during the excavation as domestic structures. Of note among these was an irregular, approximately oval ditch feature around $10 \mathrm{~m}$ of maximum diameter (visible in figure 7: 1), and a structure provisionally identified as a hut base (Fig. 7: 4). 

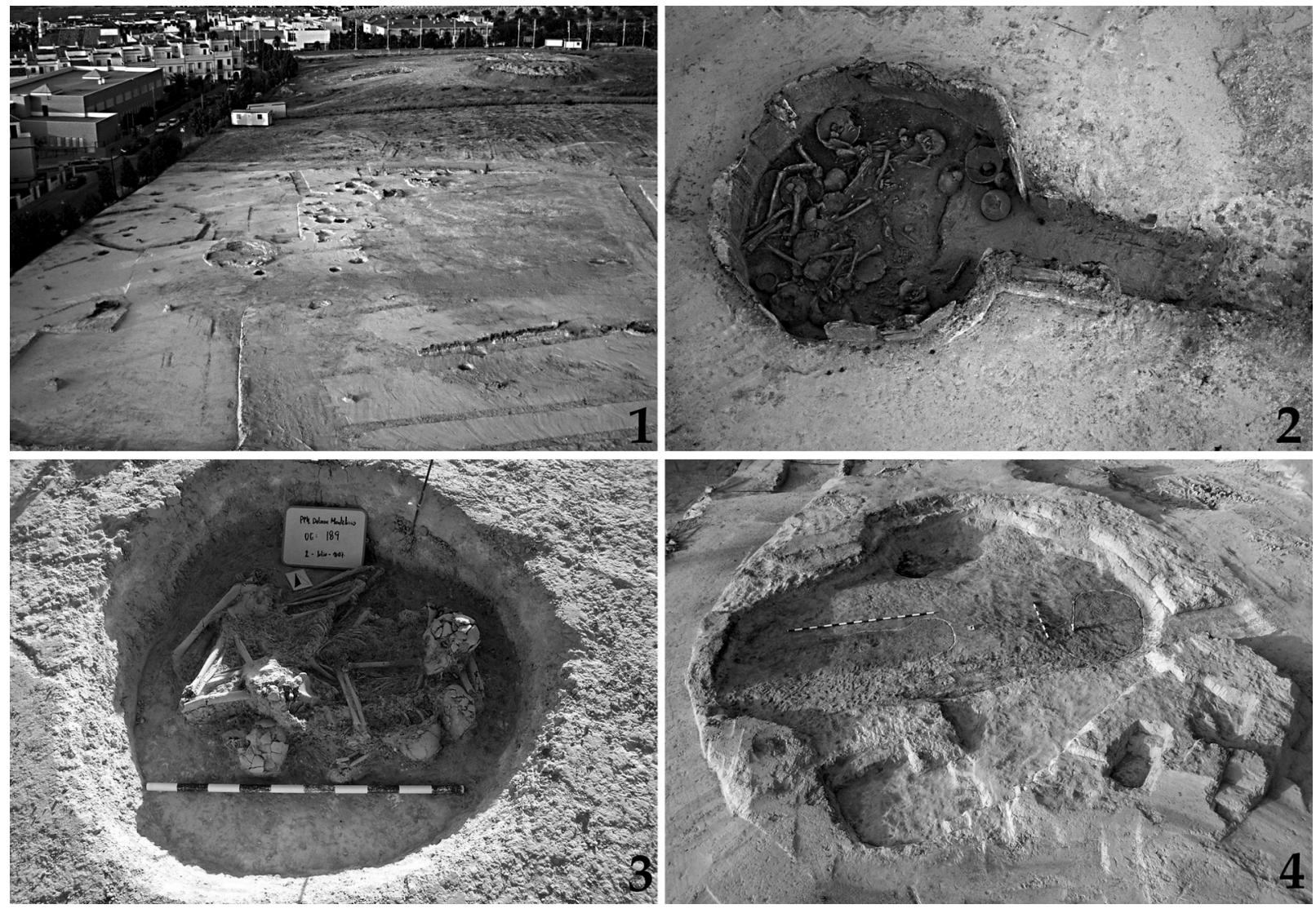

Fig. 7. 1) Aerial view of the PP4 excavations looking south. The PP4 excavation is in the foreground showing (bottom right) a double tholos tomb, and (centre and centre left) a variety of negative funerary and non-funerary structures and a ring ditch. To the left of the image is the settlement of Castilleja de Guzmán (Sevilla), while the Montelirio (Sevilla) passage grave is visible towards the upper right corner. The geophysical survey area is out of image to the right. 2) Aerial view of one of megalithic structure 10.034 of the PP4 excavation, showing in situ primary grave deposits. The chamber is approximately $2.1 \mathrm{~m}$ diameter. 3 ) example of a non-megalithic burial feature (structure 10.028) from the PP4 excavation: a collective burial within a circular cut structure. Examples of both single and collective burials are present, both with and without associated grave goods. 4) An example of a non-megalithic, non-funerary structure (structure 10.008) from the PP4 excavation provisionally interpreted as a hut-base. All photos: José Peinado Cucarella.

We now return to the geomagnetic survey discussed above to interpret the anomalies in light of the evidence from PP4. With the execption of the modern disturbance close to the main road to the south, and the remains of a fence line across the centre of the survey area, from their form and from the strength of the magnetic signal, all the features identified in the Magnetometry image are compatible with the kind of archaeological record found at PP4-Montelirio. There are at least three main concentrations of features across the area. The southernmost (Fig. 4: 2) follow the contours to the west of Montelirio. Two main types are visible: discrete pit-like features and linear features. The relatively low magnetic signal of the features further precludes them from being later industrial features such as hearths and kilns. The mixture of pit-like forms and more linear structures is extremely similar to the set of features encountered at $P P 4$, suggesting that there is likely to be a mixture of prehistoric cut features in this area. From the results, it is not possible to distinguish whether these represent burials, silos or ditches all of which are cut into the subsoil, and would be represented by similar measurements. It is also difficult to define a chronological period for these features. The presence of a small number of Roman burials at PP4 does raise 
the possibility that some of these features are later, and surface material observed around feature (m7) does appear to be Roman in date. The second concentration of features $(\mathrm{m} 11-\mathrm{m} 18)$ is similar to those mentioned above, and again could represent a mixture of structures cut into suboil of various sizes and plans. The former is supported by field observation of a disturbed prehistoric inhumation immediately to the east. The shape of feature m16 - a circular anomaly with two linear features attached at an angle - is very suggestive of the type of 'double' tholos structure, of which two were encountered at PP4.

The concentration of features to the north of the surveyed transect (Fig. 5: 2) includes a wider array of features similar in size and form to the burial chambers found at PP4-Montelirio. The close proximity of both La Pastora and Montelirio is suggestive of their potential funerary and/ or ritual character. The collection of features $(\mathrm{m} 21)$ on the hilltop could easily be seen to represent a large cluster of structures, with entrance facing to the north east (as is typical for southern Iberia) and accompanied by a series of other features. This is conjectural, as the features could equally show the location of pits and ditches on the hill. Only through excavation could such an interpretation be validated.

A further set of features on the northern edge of the survey area (m27 and m28) appears to include two substantial ditches, each some $5 \mathrm{~m}$ in width. It is apparent from the survey that one pre-dates the other, and their scale and curvilinear form may suggest that they are prehistoric in date, although this is again conjectural. It is particularly interesting to compare these with the circular ditch excavated at PP4: although the features in the geophysical survey are larger, it remains a clear possibility that these are related in some way to the Chalcolithic use of the area, either demarcating the boundary of ritual areas or perhaps indicating different phases of use of the area for different purposes. Again, only excavation will resolve the precise nature of these features.

\section{DISCUSSION}

A number of observations can be made from this fieldwork:
1) Geophysics (particularly magnetometry) has the potential to successfully locate a substantial number of archaeological features, providing evidence as to their size and shape, at a site like Valencina. The exact nature and date of the features visible in the survey results requires verification through excavation, but it is clear that the use of geophysics has significantly extended the number and range of archaeological features known in the southern sector of the site, suggesting that there is much to be gained in the future from a further systematic programme of geophysical prospecting using magnetometry. The use of other methods such as targeted use of Ground Penetrating Radar could also significantly improve the interpretation of these newly-identified structures without the immediate need for excavations.

2) Judging by the variability in size and shape, the anomalies identified in the geophysics represent various types of archaeological (architectural) structures, ranging from megalithic chambers to circular or irregular pits and large ditches. This matches exactly the range and density of features found at the PP4-Montelirio area. In particular, the survey suggests the possible existence of new chambered tombs and two large, curvilinear ditches.

3) The fact that such a diverse morphological and functional range of features appear to exist over such a large area lends support to the suggestion that the spatial organisation of the Valencina settlement is more complex than hitherto claimed, and further questions the conventional characterisation of the site as sharply divided into a burial and a domestic area. Although the evidence is still under investigation and no firm claims can be as yet made, the existence of nonmegalithic, non-funerary negative structures at PP4-Montelirio suggests that domestic structures such as storage pits, hut bases, linear or circular ditches and others may have existed in the La Pastora/Montelirio area before, during, or after its use as burial ground. Spatial overlapping (and perhaps chronological co-existence) of burial and domestic structures is evident in the northern half of Valencina (Costa Caramé et al. 2010(6)), and

(6) García Sanjuán, L. \& Díaz-Zorita Bonilla, M. in print: "Prácticas funerarias en estructuras negativas en el asentamiento prehistórico de Valencina de la Concepción (Sevilla, España): análisis contextual y osteoarqueológico". In M. Almeida (ed.): 
therefore it should not be entirely surprising that this co-existence may also exist in the southern sector of the site. Recent research at 3rd millennium sites in central Spain (Bueno Ramírez et al. 2010: 66) and southern Portugal(7) shows evidence of close spatial association between domestic and funerary structures (including megalithic monuments), occurring at certain sites, something also described in the ethnographic literature of the megalithic phenomenon (Hayden 2011: 52; Joussaume 2011). This adds credence to the possibility that the evidence found between La Pastora and Montelirio at Valencina could result from several - perhaps many - phases of use whose focus shifted over time, with the different phases of use characterised by archaelogical remains. Alternatively, the range of practices may relate to social differentiation and status, or there may be a mixture of these two processes in operation.

4) The issue of the simultaneity (or lack thereof) of use of the structures found between La Pastora and Montelirio or indeed at PP4Montelirio itself can only be resolved through a programme of radiocarbon dating both of newly excavated material and - where possible - of material that can be reliably identified from previous excavations. Experience elsewhere (Cleal et al. 1995; Bayliss et al. 2007; Whittle et al. 2007) suggests that such analysis of existing material, supported by new approaches to dating such as Bayesian calibration (Buck et al. 1991, 1992; Buck \& Sahu 2000) can enable precise and detailed chronologies to be assembled. The chronology of the entire Valencina site is also far from clear: the available radiocarbon dates suggest that activity could have extended from the early $3 \mathrm{rd}$ to the mid-2nd millennium BC. It is therefore currently unclear whether Valencina represents a single phase of occupation in which all c. 400 hectares were occupied simultaneously, or a series of occupations or activities repeated (perhaps seasonally) over more than 1500 years, or some-

Estruturas Negativas da Pré-História Recente e Proto-História Peninsulares: Estado Actual dos Conhecimentos e Interrogações (Beja, 2009). Dryas. Beja.

(7) Valera, A. C.; Márquez Romero, J. E.; Becker, H.; Jiménez Jaimez, V. \& Suárez Padilla, J. 2011 (in print): "O complexo arqueológico dos Perdigões: nova imagem e novos problemas proporcionados pela prospecção geofísica". Xelb, Actas do 8. ${ }^{\circ}$ Encontro de Arqueologia do Algarve (Silves, 25-27 Outubro, 2007), Silves, Câmara Municipal de Silves. thing between these extremes. Elsewhere in Atlantic Europe, megalithic structures of significantly greater scale such as Stonehenge (Pollard \& Ruggles 2001; Parker Pearson 2004; Parker Pearson et al. 2006) and Avebury (Whittle 1993; Pollard \& Reynolds 2002; Gillings et al. 2008) have not been shown to be associated with large, permanent settlements and appear more likely to result from less rigid forms of social organisation that may include seasonal gathering, periodic or 'tethered' sedentism (Whittle 1997).

5) This survey highlights the clear and pressing need for a systematic synthesises of previous archaeological work in all areas of the site, permitting greater comparisons between areas of the site and facilitating spatial analysis. There are limitations to what can be known from previous excavations, or deduced from non-destructive methods such as these (even when there are fortuitously adjacent rescue excavations) but a coherent chronological framework and a spatiallyreferenced archaeological database that permits interpretations to be tested against robust evidence are both essential if debates surrounding the important developments in the southern Iberian Copper Age are to be advanced.

\section{ACKNOWLEDGEMENTS}

This paper has been produced as part of the ongoing work within the research project "Comparative Analysis of the Socioeconomic dynamics of Late Prehistory in the Centre-South of the Iberian peninsula (VI-II millennia cal BCE): the South-west" (HAR2009-14360-C03-03) funded by the Spanish Ministry of Science and Innovation. The authors also acknowledge the support of INSERCO in conducting the geophysical survey, and also the Universities of Southampton and Seville. We also acknowledge the assistance of Dr Manuel Costa Caramé for access to his $\mathrm{PhD}$ research and David Knight during the geophysical survey.

\section{BIBLIOGRAPHY}

Arteaga Matute, O. \& Cruz-Auñón Briones, R. 1999: "Una valoración del Patrimonio Histórico en el campo de silos de la finca El Cuervo-RTVA (Valencina de la Concepción, Sevilla). Excavación de 
urgencia de 1995". Anuario Arqueológico de Andalucía 1995: 608-616.

Arteaga Matute, O. \& Cruz-Auñón Briones, R. 2001: "Las nuevas sepulturas prehistóricas (tholoi) y los enterramientos bajo túmulos (Tartesios) de Castilleja de Guzmán (Sevilla). Excavación de Urgencia de 1996". Anuario Arqueológico de Andalucía 1996: 640-651.

Arribas Palau, A. \& Molina González, F. 1984: “The latest excavations of the Copper Age settlement of Los Millares, Almería, Spain”. In W. Waldren, R. C. Chapman, J. Lewthwaite \& R. C. Kennard (eds.): The Deyá Conference of Prehistory. Early Settlement in the Western Mediterranean Islands and their Peripheral Areas. British Archaeological Reports International Series 229, Archaeopress. Oxford: 1029-1050.

Bayliss, A.; Bronk Ramsey, C.; Van Der Plicht, J. \& Whittle, A. 2007: "Bradshaw and Bayes: Towards a Timetable for the Neolithic". Cambridge Archaeological Journal 17: 1-28.

Blanco Ruiz, A. 1991: "Excavaciones de urgencia en el solar de la calle Duero n. ${ }^{\circ} 39$. Valencina de la Concepción, Sevilla". Anuario Arqueológico de Andalucía 1989: 430-431.

Buck, C. E.; Kenworthy, J. B.; Litton, C. D. \& Smith, A. F. M. 1991: "Combining archaeological and radiocarbon information: a Bayesian approach to calibration". Antiquity 65: 808-821.

Buck, C. E.; Litton, C. D. \& Smith, A. F. M. 1992: "Calibration of radiocarbon results pertaining to related archaeological events". Journal of Archaeological Science 19: 497-512.

Buck, C. E. \& Sahu, S. K. 2000: "Bayesian models for relative archaeological chronology building". Journal of the Royal Statistical Society. Series C (Applied Statistics) 49: 423-440.

Bueno Ramírez, P.; Bermejo Barroso, R. \& Balbín Behrmann, R. de 2010: "Entre lo visible y lo invisible: registros funerarios de la Prehistoria reciente de la Meseta Sur". En P. Bueno Ramírez, A. Gilman, C. Martín Morales \& J. Sánchez-Palencia (eds.): Arqueología, Sociedad, Territorio y Paisaje. Estudios Sobre Prehistoria Reciente, Protohistoria y Transición al Mundo Romano. En Homenaje a María Dolores Fernández Posse. Bibliotheca Prehistorica Hispana XXVIII, CSIC. Madrid: 53-73.

Cardoso, J. L. 2000: "The fortified site of Leceia (Oeiras) in the context of the Chalcolithic in Portuguese Estremadura". Oxford Journal of Archaeology 19 (1): 37-55.

Carriazo y Arroquia, J. D. M. 1962: “El dolmen de Ontiveros (Valencina de la Concepción, Sevilla)". Homenaje al Profesor Cayetano de Mergelina. Universidad de Murcia. Murcia: 209-229.
Chapman, R. W. 1990: Emerging Complexity: the Later Prehistory of South-East Spain, Iberia and the West Mediterranean. Cambridge University Press. Cambridge.

Chapman, R. W. 1995: "Urbanism in Copper and Bronze Age Iberia?". In B. Cunliffe \& S. Keay (eds.): Social Complexity and the Development of Towns in Iberia. Proceedings of the British Academy 86, British Academy. London: 29-46.

Chapman, R. W. 2008: "Producing inequalities: regional sequences in Later Prehistoric Southern Spain”. Journal of World Prehistory 21, 195-260.

Cleal, R. M. J.; Walker, K. E. \& Montague, R. 1995: Stonehenge in its landscape: twentieth century excavations. English Heritage. London.

Collantes de Terán, F. 1969: "El dolmen de Matarrubilla". Actas del V Symposium Internacional de Prehistoria Peninsular. Tartessos y sus Problemas (Jerez, 1968): 47-61. Barcelona.

Costa Caramé, M. E.; Díaz-Zorita Bonilla, M.; García Sanjuán, L. \& Wheatley, D. 2010: "The Copper Age settlement of Valencina de la Concepción (Seville, Spain): demography, metallurgy and spatial organization". Trabajos de Prehistoria 67 (1): 85177.

Cruz-Auñón Briones, R. \& Arteaga Matute, O. 1999a: "Acerca de un campo de silos y un foso de cierre prehistóricos ubicados en la Estacada Larga (Valencina de la Concepción, Sevilla). Excavación de urgencia de 1995". Anuario Arqueológico de Andalucía 1995: 600-607.

Cruz-Auñón Briones, R. \& Arteaga Matute, O. 1999b: "La Alcazaba. Un espacio social aledaño a la periferia del poblado prehistórico de Valencina de la Concepción (Sevilla). Excavación de urgencia de 1996". Anuario Arqueológico de Andalucía 1995: 701-710.

Díaz-Andreu, M. 1995: "Complex societies in Copper and Bronze Age Iberia. A reappraisal". Oxford Journal of Archaeology 14 (1): 23-39.

Díaz-del-Río, P. 2004: "Copper Age ditched enclosures in Central Iberia". Oxford Journal of Archaeology 23 (2): 107-121.

Díaz-del-Río, P. 2011: "Labor in the making of Iberian Copper Age lineages". In K. Lillios (ed.): Comparative Archaeologies: the US Southwest and the Iberian Peninsula. Oxbow. Oxford: 37-56.

Esquivel Guerrero, J. A. \& Navas Guerrero, E. 2005: "The geometry and the metric used in the enclosure Fortín 1 at Copper Age site of Los Millares (Almería, Andalusia)". Journal of Archaeological Science 32: 1577-1586.

Esquivel Guerrero, J. A. \& Navas Guerrero, E. 2007: "Geometric architectural pattern and constructive energy analysis at Los Millares Copper Age Settlement (Santa Fe de Mondújar, Almería, Andalusia)". Journal of Archaeological Science 34: 894-904. 
Fernández Gómez, F. \& Oliva Alonso, D. 1986: "Valencina de la Concepción (Sevilla): Excavación de urgencia”. Revista de Arqueología 58: 19-33.

Fernández Gómez, F. \& Ruiz Mata, D. 1978: “El tholos del Cerro de la Cabeza, en Valencina de la Concepción (Sevilla)". Trabajos de Prehistoria 35: 193-224.

Gaffney, C.; Gater, J. \& Ovenden, S. 1991: The use of geophysical techniques in archaeological evaluations. Institute of Field Archaeologists. Technical Papers. University of Birminghan. Birminghan.

García Sanjuán, L. 2009: "Seville”. In L. García Sanjuán \& B. Ruiz González (eds.): The Large Stones of Prehistory. Megalithic Sites and Landscapes of Andalusia. Junta de Andalucía. Sevilla: 228-259.

Geoscan Research 1996: RM15 Resistance Meter: Instruction Manual. Version 2.4. Geoscan Research. Bradford, England.

Gillings, M.; Pollard, J.; Wheatley, D. \& Peterson, R. 2008: Landscape of the Megaliths: Excavation and Fieldwork on the Avebury Monuments 1997-2003. Oxbow. Oxford.

Gilman, A. 1987: "Unequal development in Copper Age Iberia”. In E. M. Brumfiel \& T. K. Earle (eds.): Specialization, Exchange and Complex Societies. Cambridge University Press. Cambridge: 22-29.

Gilman, A. 2002: “Assessing political development in Copper and Bronze Age Southeast Spain". In J. Haas (ed.): From Leaders to Rulers. Kluwer Academic/Plenum Publishers. New York: 59-81.

Gómez de Terreros Guardiola, M. G. 2005: Intervenciones en Dólmenes, 1953-1964. Proyectos y Obras de Félix Hernández Giménez. Dólmenes de Matarrubilla y Cueva de la Pastora (Valencina de la Concepción, Sevilla), Dolmen de Zancarrón de Soto (Trigueros, Huelva). Universidad de Sevilla. Sevilla.

Gómez de Terreros Guardiola, M. G. 2008: "Dólmenes de Cueva de la Pastora, Matarrubilla y Zancarrón de Soto. Historia de sus intervenciones". In L. García Sanjuán (coord.): Patrimonio Megalítico. PH 67. Boletín del Instituto Andaluz del Patrimonio Histórico. Instituto Andaluz del Patrimonio Histórico. Seville: 146-157.

Hayden, B. 2011: "Feasting and social dynamics in the Epipaleolithic of the fertile crescent: an interpretive exercise". In G. Aranda Jiménez, S. Montón-Subías \& M. Sánchez Romero (eds.): Guess Who's Coming to Dinner: Feasting Rituals in the Prehistoric Societies of Europe and the Near East. Oxbow. Oxford: 30-63.

Hurtado Pérez, V. 2000: "Surface survey analysis of the Copper Age site of La Pijotilla (Spain)". In R. Francovich \& H. Patterson (eds.): Extracting Meaning from Ploughsoil Assemblages. The Archaeology of Mediterranean Landscapes 5, Oxbow. Oxford: 121-130.
Hurtado Pérez, V. 2004: "San Blas. The discovery of a large chalcolithic settlement by the Guadiana river". Journal of Iberian Archaeology 6: 93-116.

Hurtado Pérez, V. 2010: "The ditched enclosures of the middle Guadiana Basin". A. C. Valera \& L. Shaw Evangelista (eds.): Proceedings of the $X V$ UISPP Congress (Lisbon, September 4-9 2006). Session WS29: The Idea of Enclosure in Recent Iberian Prehistory. British Archaeological Reports International Series 2124, Archaeopress. Oxford: 161-167.

Joussaume, R. 2011: "A journey through the world of recent megaliths". In L. García Sanjuán, C. Scarre \& D. W. Wheatley (eds.): Exploring Time and Matter in Prehistoric Monuments: Absolute Chronology and Rare Rocks in European Megaliths. Menga: Journal of Andalusian Prehistory, Monograph 1. Junta de Andalucía. Sevilla.

Kohring, S.; Odriozola Lloret, C. \& Hurtado Pérez, V. 2007: "Materialising 'complex' social relationships: technology, production and consumption in a Copper Age community". In S. Kohring \& S. Wynne-Jones (eds.): Socialising Complexity. Structure, Interaction and Power in Archaeological Discourse. Oxbow. Oxford: 100-117.

López Aldana, P.; Sánchez Liranzo, O.; Pajuelo Pando, A.; Ruiz Aguilar, S.; Vera Fernández, A.; García Morales, I. \& Velasco Contreras, M. 2001: "Excavación de Urgencia en una estructura habitacional en Valencina de la Concepción (Sevilla)". Anuario Arqueológico de Andalucía 1997: 623-630.

Marshall, A. 1999: "Magnetic prospection at high resolution: survey of large silopits in Iron Age enclosures". Archaeological Prospection 6: 11-29.

Martín de la Cruz, J. C. \& Miranda Ariz, J. M. 1988: "El poblado calcolítico de Valencina de la Concepción (Sevilla). Una revisión crítica”. Cuadernos de Prehistoria y Arqueología de la Universidad Autónoma de Madrid 15: 37-67.

Martín Espinosa, A. \& Ruiz Moreno, M. T. 1992: “Excavación de urgencia en la finca La Gallega, 1. ${ }^{\mathrm{a}} \mathrm{Fa}-$ se. Valencina de la Concepción, Sevilla”. Anuario Arqueológico de Andalucía 1990: 455-458.

Martín Espinosa, A. \& Ruiz Moreno, M. T. 1995: “Excavación en el dolmen de La Pastora (Valencina de la Concepción, Sevilla). Revisión y actualización de las investigaciones". Actas del XXII Congreso Nacional de Arqueología (Vigo, 1993): 417-420. Vigo.

Micó Pérez, R. 1995: “Los Millares and the Copper Age of the Iberian Southeast". In K. Lillios (ed.): The Origins of Complex Societies in Late Prehistoric Iberia. International Monographs in Prehistory, Archaeological Series 8. Ann Arbor: 169-176.

Morán Hernández, E. 2010: “O povoado calcolítico de Alcalar: organização do espaço e sequência ocupacional". In V. S. Gonçalves \& A. C. Sousa 
(eds.): Transformação e Mudança no Centro e Sul de Portugal: o 4. ${ }^{\circ}$ e o $3 .^{\circ}$ milénios a.n.e. Actas do Colóquio Internacional (Cascais, 2005): 325-331. Cascais.

Morán Hernández, E. 2010: "Spatial organisation of the Alcalar Copper Age settlement (Algarve, Portugal)". In A. C. Valera \& L. Shaw Evangelista (eds.): Proceedings of the XV UISPP Congress (Lisbon, September 4-9 2006). Session WS29: The Idea of Enclosure in Recent Iberian Prehistory. British Archaeological Reports International Series 2124. Archaeopress Oxford: 161-167.

Müller, R. \& Cardoso, J. L. 2008: "The origin and use of copper at the Chalcolithic fortification of Leceia (Oeiras, Portugal)". Madrider Mitteilungen 49: 64-94.

Müller, R. \& Monge Soares, A. 2008: “Traces of early copper production a the Chalcolithic fortification of Vila Nova de Sao Pedro (Azambuja, Portugal)". Madrider Mitteilungen 49: 94-114.

Murillo Díaz, M. T. 1991: "Excavaciones de urgencia en el poblado calcolítico de Valencina de la Concepción. Sevilla, 1988-1989”. Anuario Arqueológico de Andalucía 1989: 561-562.

Murillo Díaz, M. T. 2001: "Historia de las investigaciones y bibliografía del asentamiento prehistoria de Valencina de la Concepción (Sevilla)". Revista de Humanidades 12: 29-44.

Murillo Díaz, M. T.; Cruz-Auñón Briones, R. \& Hurtado Pérez, V. 1990: "Excavaciones de urgencia en el yacimiento calcolítico de Valencina de la Concepción (Sevilla)". Anuario Arqueológico de Andalucía 1988: 354-359.

Murillo Díaz, M. T.; Pérez, C.; Blanco, A. \& Larrey, E. 1987: "Excavación en el yacimiento calcolítico del Polideportivo de Valencina de la Concepción (Sevilla), 1985". Anuario Arqueológico de Andalucía 1985: 311-315.

Navas Guerrero, E.; Esquivel Guerrero, J. A. \& Molina González, F. 2008: "Butchering patterns and spatial distribution of faunal animal remains consumed at the Los Millares chalcolithic settlement (Santa Fe de Mondújar, Almería, Spain)". Oxford Journal of Archaeology 27 (4): 325-339.

Nocete Calvo, F. 2006: "The first specialised copper industry in the Iberian peninsula: Cabezo Juré (2900-2200 BC)". Antiquity 80: 646-654.

Nocete Calvo, F.; Queipo de Llano, G.; Sáenz, R.; Nieto, J. M.; Inácio, N.; Bayona, M. R.; Peramo, A.; Vargas Jiménez, J. M.; Cruz-Auñón Briones, R.; Gil-Ibarguchi, J. \& Santos, J. F. 2008: "The smelting quarter of Valencina de la Concepción (Seville, Spain): the specialised copper industry in a political centre of the Guadalquivir valley during the Third Millennium BC (2750-2500 BC)". Journal of Archaeological Science 35: 717-732.

Obermaier, H. 1919: El Dolmen de Matarrubilla (Sevilla). Memorias de la Comisión de Investigaciones
Paleontológicas y Prehistóricas 26. Museo de Ciencias Naturales. Madrid.

Parker Pearson, M. 2004: "Earth, wood and fire: materiality and Stonehenge". In N. Boivin \& M. A. Owoc (eds.): Soils, stones and symbols: cultural perceptions of the mineral world.. UCL Press. London.

Parker Pearson, M.; Pollard, J.; Richards, C.; Thomas, J.; Tilley, C.; Welham, K. \& Albarella, U. 2006: "Materializing Stonehenge: the Stonehenge Riverside Project and new discoveries". Journal of Material Culture 11: 227-261.

Pollard, J. \& Reynolds, A. 2002: Avebury: the biography of a landscape. Tempus. Stroud.

Pollard, J. \& Ruggles, C. 2001: "Shifting perceptions: spatial order, cosmology, and patterns of deposition at Stonehenge". Cambridge Archaeological Journal 11: 69-90.

Ruiz Mata, D. 1983: "El yacimiento de la Edad del Bronce de Valencina de la Concepción (Sevilla) en el marco cultural del Bajo Guadalquivir". Actas del I Congreso de Historia de Andalucía (Córdoba, diciembre de 1976): 183-208. Monte de Piedad y Caja de Ahorros de Córdoba. Córdoba.

Ruiz Moreno, M. T. 1991: “Excavación arqueológica de urgencia en Valencina de la Concepción, urbanización La Cima (Sevilla), 1989-1990”. Anuario Arqueológico de Andalucía 1989: 461-464.

Ruiz Moreno, M. T. 1995: "Valencina de la Concepción. Avance a la Carta Arqueológica". Actas del XXIII Congreso Nacional de Arqueología (Elche, 1995): 37-42. Ayuntamiento de Elche. Elche.

Ruiz Moreno, M. T. 1999: “Excavación arqueológica de urgencia en la urbanización El Mirador de Itálica (Valencina de la Concepción, Sevilla)". Anuario Arqueológico de Andalucía 1994: 511-516.

Ruiz Moreno, M. T. \& Martín Espinosa, A. 1993: "Excavación de urgencia en el dolmen de La Pastora, Valencina de la Concepción, Sevilla". Anuario Arqueológico de Andalucía 1991: 554-558.

Ruiz Moreno, M. T. \& Martín Espinosa, A. 1995: "Nuevos datos en torno al Dolmen de la Pastora (Valencina de la Concepción, Sevilla)". Actas do $1^{\text {er }}$ Congresso de Arqueologia Peninsular (Porto, 1993): 81-83. Porto.

Santana Falcón, I. 1991: "Excavación arqueológica de emergencia en un dolmen del término municipal de Castilleja de Guzmán (Sevilla)". Anuario Arqueológico de Andalucía 1989: 446-449.

Santana Falcón, I. 1993: "Excavación arqueológica de urgencia en El Algarrobillo, Valencina de la Concepción (Sevilla)". Anuario Arqueológico de Andalucía 1991: 548-553.

Scollar, I.; Tabbagh, A.; Hesse, A. \& Herzog, I. 1990: Archaeological Prospecting and Remote Sensing. Cambridge University Press. Cambridge. 
Tubino, F. M. 1876: "Los monumentos megalíticos de Andalucía, Extremadura y Portugal y los aborígenes ibéricos". Museo Español de Antigüedades 7: 303-364.

Vargas Jiménez, J. M. 2004a: Carta Arqueológica Municipal de Valencina de la Concepción. Junta de Andalucía. Sevilla.

Vargas Jiménez, J. M. 2004b: "Elementos para la definición territorial del yacimiento prehistórico de Valencina de la Concepción (Sevilla)". SPAL. Revista de Prehistoria y Arqueología 12: 125-144.

Vera Fernández, A.; Ruiz Aguilar, S. \& Lacalle Rodríguez, R. 2002: "Intervención arqueológica de urgencia en el M-1 del Plan Parcial 3. Castilleja de
Guzmán. Sevilla". Anuario Arqueológico de Andalucía 1999: 993-1004.

Whittle, A.; Barclay, A.; Bayliss, A.; Mcfadyen, L.; Schulting, R. \& Wysocki, M. 2007: "Building for the dead: events, processes and changing worldviews from the thirty-eighth to the thirty-fourth Centuries cal. BC in Southern Britain". Cambridge Archaeological Journal 17: 123-147.

Whittle, A. W. R. 1993: "The Neolithic of the Avebury area: sequence, environment, settlement and monuments". Oxford Journal of Archaeology 12: 29-53.

Whittle, A. W. R. 1997: "Moving on and moving around: Neolithic settlement mobility". In P. Topping (ed.): Neolithic Landscapes. Oxbow. Oxford: 15-22. 